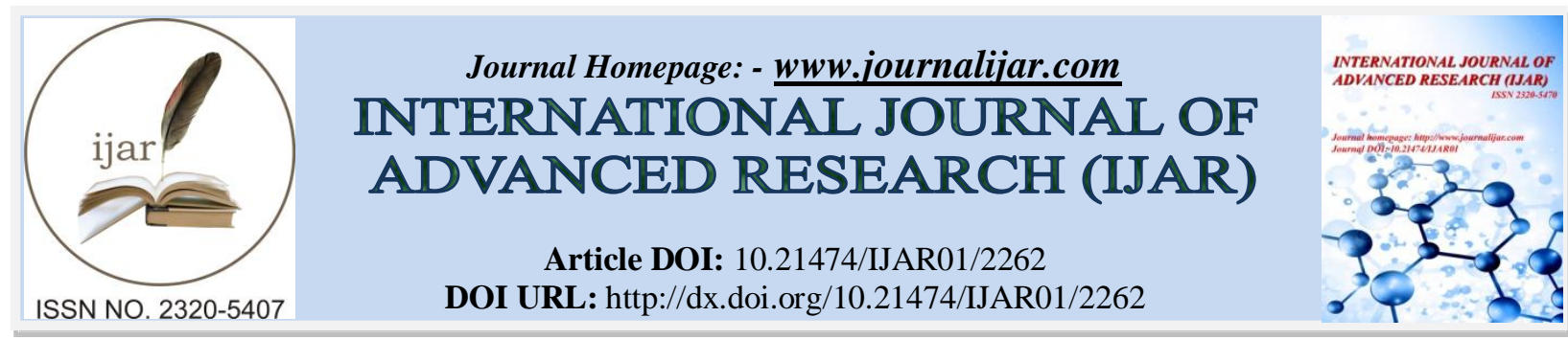

RESEARCH ARTICLE

\title{
ASSESSMENT OF BIOENERGY POTENTIAL OF CROP RESIDUES THROUGH SPATIAL DISTRIBUTION AND AVAILABILITY PERSPECTIVES: A CASE STUDY OF JALGAON DISTRICT (MS) INDIA.
}

\author{
Yogesh V. Narkhede ${ }^{1}$, Gulab S. Tadvi ${ }^{2}$ and ${ }^{*}$ Ketan P. Narkhede ${ }^{1}$. \\ 1. Department of Microbiology, Moolji Jaitha College, Jalgaon, Maharashtra, India 425001. \\ 2. Department of Geography, Moolji Jaitha College, Jalgaon, Maharashtra, India 425001.
}

\section{Manuscript Info}

\section{Manuscript History}

Received: 29 September 2016

Final Accepted: 30 October 2016

Published: November 2016

Key words:-

Biomass potential, Crop residue,

Geographical Information System

\begin{abstract}
Biomass waste obtained from agro-industry can serve as a suitable substrate for ethanol production. However, it has a major limitation regarding availability of systematic information related to distribution of biomass among the region. Present work focused on development of a systematic approach for estimation of bioenergy potential of agricultural waste through a case study of Jalgaon district over the period 2009-2013. Estimated average residue yield of major crops of the region was calculated using experimentally derived values of crop residual index and secondary data of crop yield generated through various sources. The crop wise availability and its density in the region were demonstrated by Geographical Information System (GIS) mapping technique. The carbohydrate and thermal potential of the region was also derived which will help to enlighten the opportunities and challenges for bioenergy sector in the region. It was found that on an average 0.75 million metric tons of lignocellulosic biomass was produced during 2009-13 with highest density of crop residues recorded in the North and North East parts of the District. Annual thermal and carbohydrate potential of the district was recorded as 12.433 PJ and 437. 84 thousand Metric tons, respectively.
\end{abstract}

Copy Right, IJAR, 2016,. All rights reserved.

\section{Introduction:-}

India is one of the largest energy consuming countries of Asia, whose energy consumption is mainly fossil fuel dependant (Valdez et al., 2010). In recent years, the consumption of petroleum products in the country is increased by 5-6 per cent per annum. At present around 60 per cent of India's power generation capacity is based on coal and net coal import dependency has risen from a negligible percentage in 1990 to nearly 23 per cent in 2014. In addition to this, country's fuel oil import also found increased up to 28 per cent of India's total energy needs (MNRE Annual Report, 2015). Therefore, investigation regarding potential alternate energy sources which are renewable, sustainable, efficient, cost effective and safe is major challenge to Indian scientists (Prasad et al., 2007).

Being an agricultural based country, India has capacity to produce large amount of biomass which can be utilized as an alternate and renewable source of energy. Bioenergy capacity of India is recorded as $4272 \mathrm{M}$ Watt against estimated potential of $25 \mathrm{G}$ Watt (MNRE Annual Report, 2015). Indian agro industry produces huge amount of lignocellulosic biomass as low cost byproduct. It includes field residues like Wheat straw, Jawar straw, Corn stover, 
Cotton stalks and process residues like Ground nut shell, Green gram husk, Black gram husk, Red gram husk etc. (Raj et al., 2015; Sarkar et al., 2012). Globally many agro-residues have been used to produce bio- ethanol such as rice-straw, wheat straw, sugarcane bagasse, sugarcane tops, cotton stalk, soft bamboo, bamboo processing wastes and all are considered as abundantly available feed stocks (Gupta and Verma, 2015; Saxena et al., 2009).

To utilize available biomass entirely for bioenergy, it is necessary to establish a systematic approach for assessment of bioenergy potential of agricultural and agro based industries. Haase et al. (2016) established a Geographical Information System based approach for sustainable utilization of crop residue potential of European region. It was applied to analyze the availability and the spatial distribution of cereal straw, root crop and oil plant residues for European regions. Spatially differentiated environmental sustainability issues, such as organic carbon content in topsoil, soil erodibility, and protected areas were considered for GIS mapping. Moreover, in another study GISbased technique was used for assessment of banana residual biomass potential for ethanol production and power generation. It involve the parameters such as lower heating value and carbohydrate analysis which were used in combination with GIS based data to reveal the clear picture of biomass potential (Guerrero et al., 2016).

The present research is focused on assessment of availability and distribution of crop residues in Jalgaon district using GIS approach with secondary data from various sources. Initially, total yield of post harvest residues of major crops of the region such as Jawar, Wheat, Corn, Pearl millet, Red gram, Green gram, Black gram, Soybean, Ground nut and cotton was calculated followed by simulation of its spatial distribution. Further, the total crop residue availability was used to calculate bioenergy potential of the region.

\section{Materials And Methods:-}

1. Crop residual index (CRI) of major crops of Jalgaon district:-

Crop residual index is defined as ratio of the amount of residues generated per unit yield. The availability of crop residues was thereby obtained based upon the average yield of crops during 2009-13. To calculate crop residue index, 10 samples of each matured plant of above listed crops were selected from random fields of local region. They were brought in to the laboratory and grains/product and post harvest residues from each sample were separated, oven dried at $105 \pm 3^{0} \mathrm{C}$ and weighed to calculate crop residual index (Peidong et al., 2007). These experimentally derived CRI values were utilized to calculate total crop residue of the region.

\section{Total yield of crop residues of the region:-}

The data of crop yield of the district for the year 2009-13 was collected from Department of Statistics and Economics, Government of Maharashtra, India (District statistical Abstract, DES Govt. of Maharashtra 2009-13). The total crop residue yield was calculated in terms of thousand Mt. tons mentioned in the data table 1 given in result section.

\section{Spatial distribution of crop residues:-}

The map of farmland distribution of Jalgaon district was generated at scale 1:1000000 (Fig. 1). Based on this map and regional crop yield, Tahsil (province) wise density and distribution of crop residue was assigned to respective farmland area. All the simulations were performed by Arc Map 9.3 software.

\section{Analysis of crop residues for energy potential:-}

To understand energy characteristics of crop residues, calorific value of dry biomass were calculated which is useful to comment on thermal energy potential. It was estimated by Digital Bomb Calorimeter (Toshniwal Inc., India) (Naik et al., 2010; Demirbaş, 2001). Holocellulose content of crop residues was estimated spectrophotometrically at $490 \mathrm{~nm}$ by using Phenol Sulfuric assay. The cellulose (A. R. grade Himedia, Mumbai) was used to prepare standard curve (Sadasivam and Manickam, 2008).

\section{Results And Discussion:-}

1. Crop residual index:-

All major crops of Jalgaon district such as Jawar, Wheat, Pearl millet, Cotton, Groundnut, Soybean, Greengram, Redgram, and Blackgram were analyzed for crop residual index. The CRI values derived for each individual crop were listed in Table 1 are used to estimate crop residue potential of the region. 


\section{Total crop residue yield:-}

The statistical analysis and map of average total crop residue yield (Fig. 2) showed that highest density of crop residues were found at North and North-East (Raver, Yawal, Muktainagar, and Bhusaval) and East regions (Amalner, Dharangaon, Parola, Bhadgaon) of the district. Crop wise distribution study revealed that cereal crops viz. Jawar, Cotton Wheat, and Corn were found as major crops with the generation of around $26.34 \%, 16.36 \% 14.72 \%$, and $9.90 \%$ of crop residues, respectively (Table 1 ).

Temporal variation in crop residue yield was also noted in the region during 2009-13 (Fig. 3). The total crop residue yield estimated during 2009-10 was found around 1 million Mt. Tons. In later three it was found to be decreased and average total yield was estimated 0.775 million Mt. Tons.

\section{Spatial distribution of crop residues:-}

Crop wise analysis helped to reveal crop specific density distribution of regions in the district. Jawar was found as major crop of district which produce higher crop resides in most of the regions except Erandol and Bodwad (Fig. 4). Wheat was recorded as second highest available crop residues and found concentrated in the Northern Tahsils of the district like Raver, Yawal and Chopda (Fig. 5). Cotton was observed to be another major crop of the district with highest cotton residue recorded at Jamner and Chopda Tahsil (Fig. 6). Figure 7 described density and distribution of Corn residues and it was found to be concentrated in Raver, Pachora and Jamner Tahsils.

\section{Bioenergy potentials of crop residues in Jalgaon district:-}

Calorific value reflects the thermal Energy potential of dry biomass which is used in combustion or gasification processes. In Jalgaon district, it was estimated to be $12.433 \mathrm{PJ}$ per annum. Out of which around half of contribution is made by cereal crops residues. To study liquid fuel prospects of crop residues, it is necessary to consider carbohydrate potential of the biomass. Hence in the present study, holocellulose content of dry biomass was estimated which enlighten second generation ethanol ability of the region. Total carbohydrate potential of the region was estimated around $437.83 \mathrm{Th}$. Mt. Tons per annum. Jawar residues were recorded as major carbohydrate source in the region generates around 30 per cent holocellulose as compared to others (Table 2).

Jiang et al., (2012) have assessed energy bio potential of China as 7.4 EJ/year, which account for 8.27 per cent of total energy consumption of the country in 2009. It was estimated on the basis of theoretical data available through various sources. In present study, Bioenergy potential of crop residues of Jalgaon District, (MS) India was estimated on the basis of both available data and experimental values obtained for crop residual index and calorific value. It will be helpful for policymakers for promote region specific alternate energy options in the country viz. Gasification, pyrolysis, biochemical conversion and fermentation (Kumar et al., 2015). Also it can be forwarded as study model and may implemented similar approach to discuss Bioenergy potential for states or country.

\section{Conclusion:-}

At Indian subcontinent, agro industrial waste is available in ample quantity and has potential to serve as low cost and sustainable source of biomass for green energy. Yet lack of handful data of availability, sustainability, distribution and characterization of biomass at specific locations build a challenge to develop lignocellulose based energy plants and refineries. GIS mapping tool is found to be useful to detect the density and distribution of agricultural residues. Also it is helpful to study supply chain and optimize the site selection of conversion facility in context of transport cost. Jawar was recorded as major crop of the region produced around 197 thousand metric tons of crop residues per annum with high density all over district except few Tahsils like Jalgaon, Erandol and Dharangaon. However, in case of other major crops viz. Wheat (122 thousand metric tons), cotton (110 thousand metric tons) and corn (74 thousand metric tons); densities of crop residues were concentrated to few specific locations of the district. The thermal and carbohydrate potential of crop residues were recorded suitable for energy production by pyrolysis and fermentation, respectively. Thus, the study revealed the theoretical potential of the region in context to alternate energy. The estimated energy potential of the region serves as direction for selection of biomass for fuel production to small scale industries and entrepreneurs in energy sectors. In Jalgaon district, cereal crop residues like Jawar, Wheat, and Corn along with Cotton are found potential source of lignocellulosic biomass. In addition to this, present research may serve as model for other location specific biomass studies. 


\section{Acknowledgement:-}

The authors are thankful to KCEs Moolji Jaitha College, Jalgaon, (MS) India for the laboratory and library facility. Also authors would like to thank North Maharashtra University, Jalgaon, (MS), India for financial support through Shri. Gyanchand H. Raisoni Doctoral Fellowship to carry this work.

Table 1:- Per cent distribution of crops yield and crop residues in Jalgaon district during 2009-13

\begin{tabular}{|l|l|l|l|l|}
\hline Crop & $\begin{array}{l}\text { Yield } \\
\text { (Th. Mt. Tons/year) }\end{array}$ & CRI & $\begin{array}{l}\text { Residue } \\
\text { (Th. Mt. Tons/year) }\end{array}$ & Per cent \\
\hline Jawar & 173.301 & 1.14 & 197.563 & 26.34 \\
\hline Cotton & 82.346 & 1.49 & 122.696 & 16.36 \\
\hline Wheat & 74.631 & 1.48 & 110.454 & 14.72 \\
\hline Corn & 65.736 & 1.13 & 74.282 & 9.90 \\
\hline Blackgram & 20.257 & 3.60 & 72.925 & 9.72 \\
\hline Soybean & 24.727 & 2.46 & 60.828 & 8.11 \\
\hline Greengram & 19.363 & 2.98 & 57.702 & 7.69 \\
\hline Pearl millet & 27.577 & 1.28 & 35.299 & 4.71 \\
\hline Redgram & 10.671 & 1.44 & 15.366 & 2.05 \\
\hline Groundnut & 1.409 & 2.16 & 3.043 & 0.41 \\
\hline & 500.018 & & 750.158 & \\
\hline
\end{tabular}

Table 2: Thermal energy and carbohydrate potential of crop resides

\begin{tabular}{|l|l|l|l|l|l|l|l|}
\hline Crop & $\begin{array}{l}\text { Residue (Th. } \\
\text { Mt. Tons) }\end{array}$ & $\begin{array}{l}\text { Calorific } \\
\text { Value } \\
\left({ }^{\mathrm{a} K c a l / k g)}\right.\end{array}$ & \multicolumn{2}{l|}{ Energy Potential } & \multicolumn{2}{l|}{$\begin{array}{l}\text { Holocellulose } \\
(\mathrm{mg} / \mathrm{g}) \\
\text { biomass }\end{array}$} \\
& & & $\begin{array}{l}\text { Amount } \\
\text { of }\end{array}$ & Per cent & & \multicolumn{2}{l|}{ Carbohydrate potential } \\
\hline & & & & $\begin{array}{l}\text { Amount (Th. } \\
\text { Mt. Tons })\end{array}$ & Per cent \\
\hline Jawar & 197.563 & 4152.58 & 3.433 & 27.61 & 663.8 & 131.14 & 29.95 \\
\hline Wheat & 110.454 & 3276.42 & 1.514 & 12.18 & 613.0 & 67.71 & 15.46 \\
\hline Cotton & 122.696 & 3981.38 & 2.044 & 16.44 & 518.8 & 63.65 & 14.54 \\
\hline Corn & 74.282 & 4184.08 & 1.300 & 10.46 & 749.3 & 55.66 & 12.71 \\
\hline Soybean & 60.828 & 4201.37 & 1.069 & 8.60 & 589.9 & 35.88 & 8.20 \\
\hline Greengram & 57.702 & 4205.33 & 1.015 & 8.17 & 543.5 & 31.36 & 7.16 \\
\hline Blackgram & 72.925 & 4030.00 & 1.230 & 9.89 & 315.9 & 23.04 & 5.26 \\
\hline Pearl millet & 35.299 & 3503.11 & 0.517 & 4.16 & 526.1 & 18.57 & 4.24 \\
\hline Redgram & 15.366 & 3981 & 0.256 & 2.06 & 600.0 & 9.22 & 2.11 \\
\hline Groundnut & 3.043 & 4312.85 & 0.055 & 0.44 & 526.1 & 1.60 & 0.37 \\
\hline Total & 750.158 & & 12.433 & 100.00 & & 437.84 & 100.00 \\
\hline
\end{tabular}

${ }^{a}-1$ kilocalorie $=4184$ Joule is used for the thermal potential calculation.

Figure 1:- Tahsil wise location map of Jalgaon district

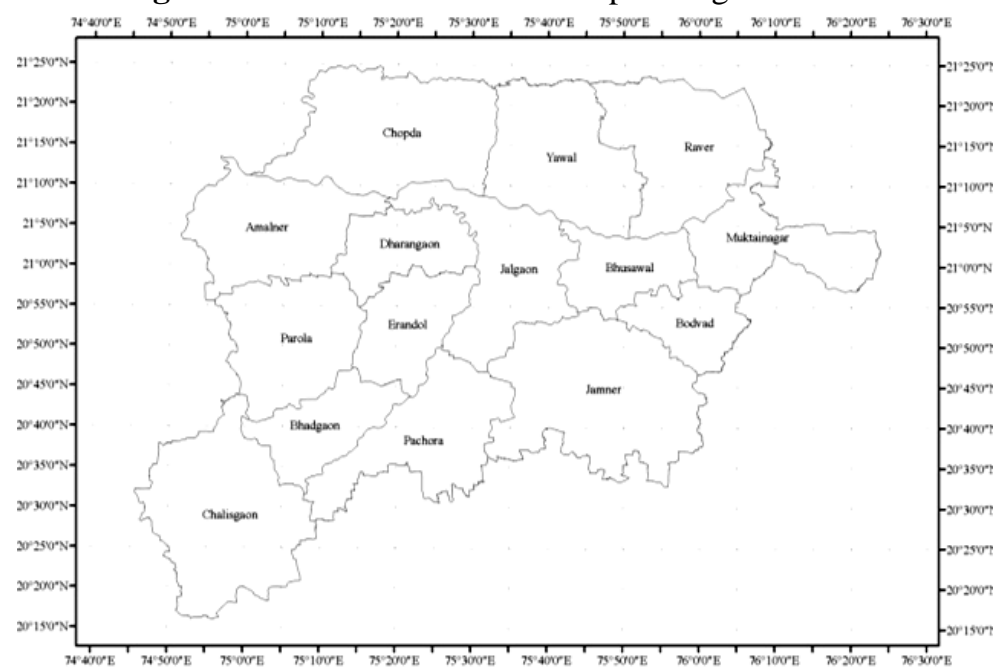


Figure 2:- Spatial distribution of average crop residues in Jalgaon district during 2009-13

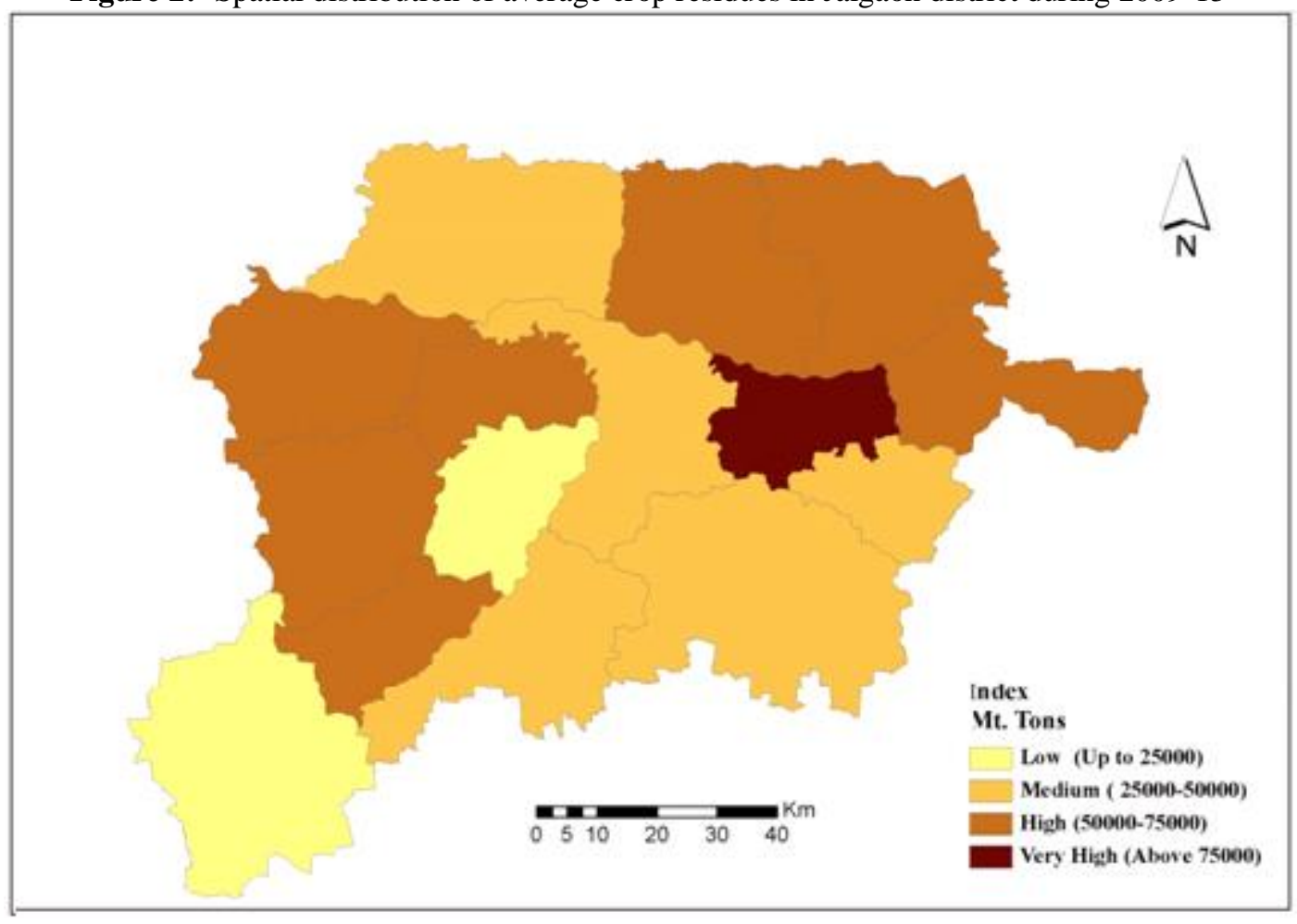

Figure 3:- Temporal Variation of crop residue during 2009-2013

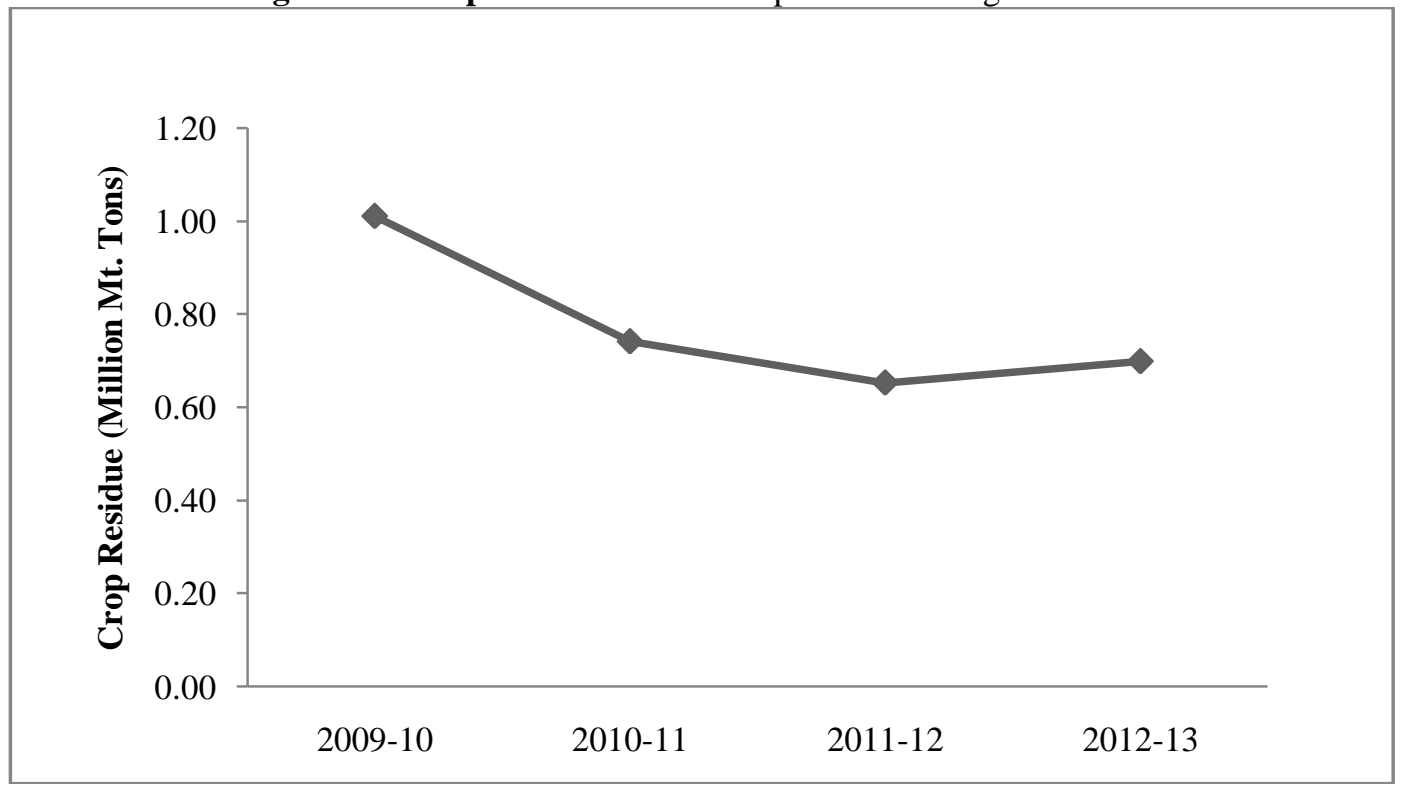


Figure 4:- Spatial distribution of Jawar crop residues in Jalgaon district during 2009-13 (in Mt. Tons)

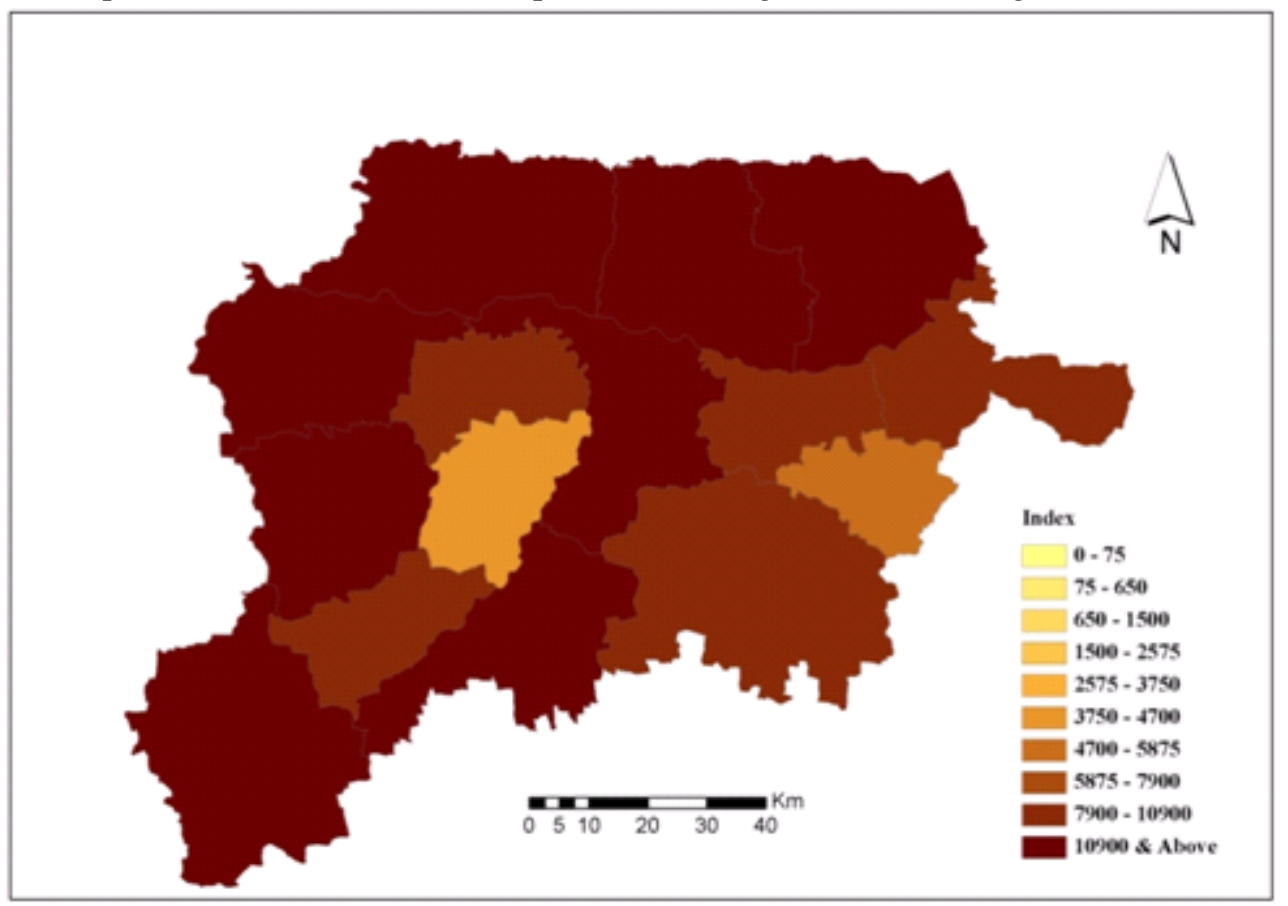

Figure 5:- Spatial distribution of Wheat crop residues in Jalgaon district during 2009-13 (in Mt. Tons)

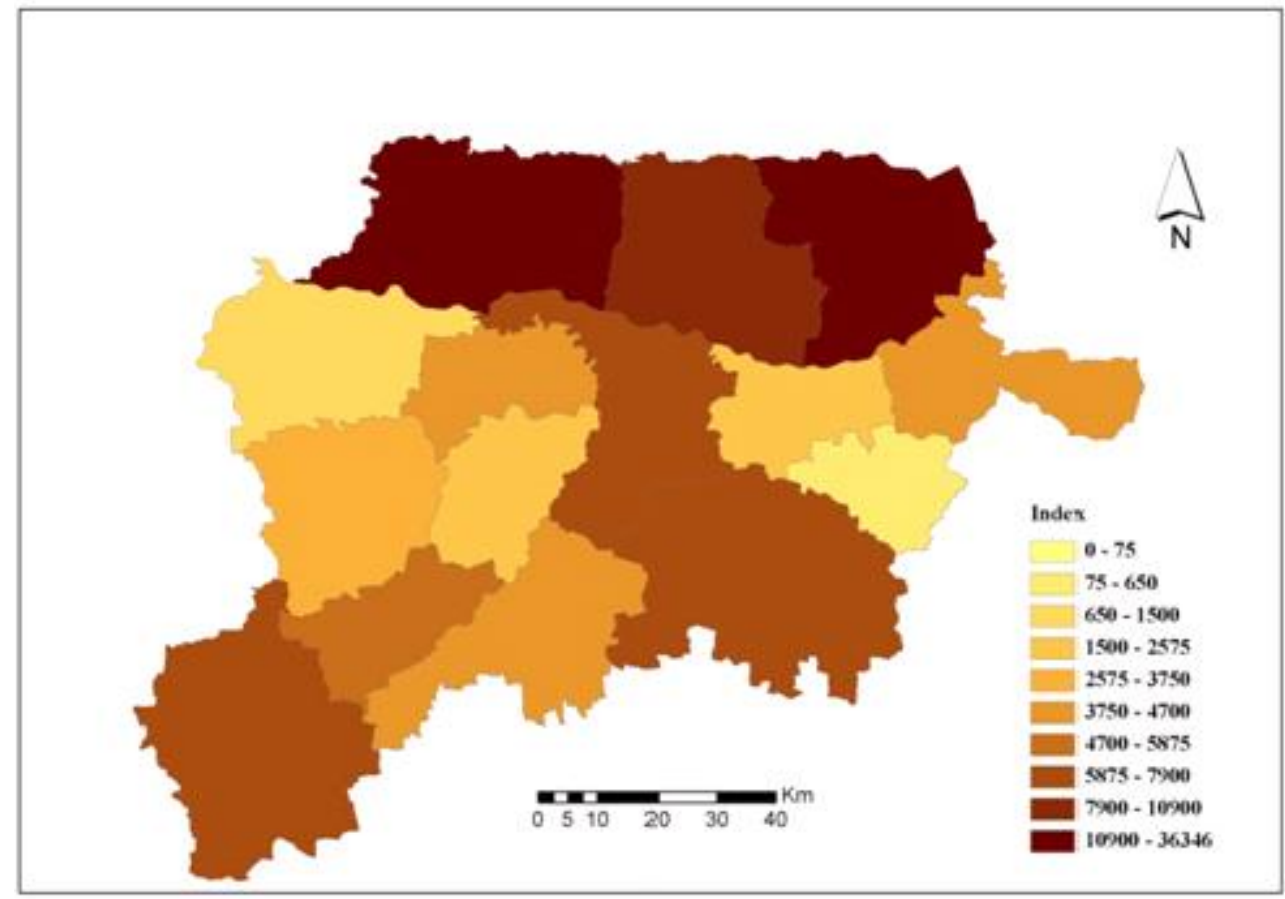


Figure 6:- Spatial distribution of Cotton crop residues in Jalgaon district during 2009-13 (in Mt. Tons)

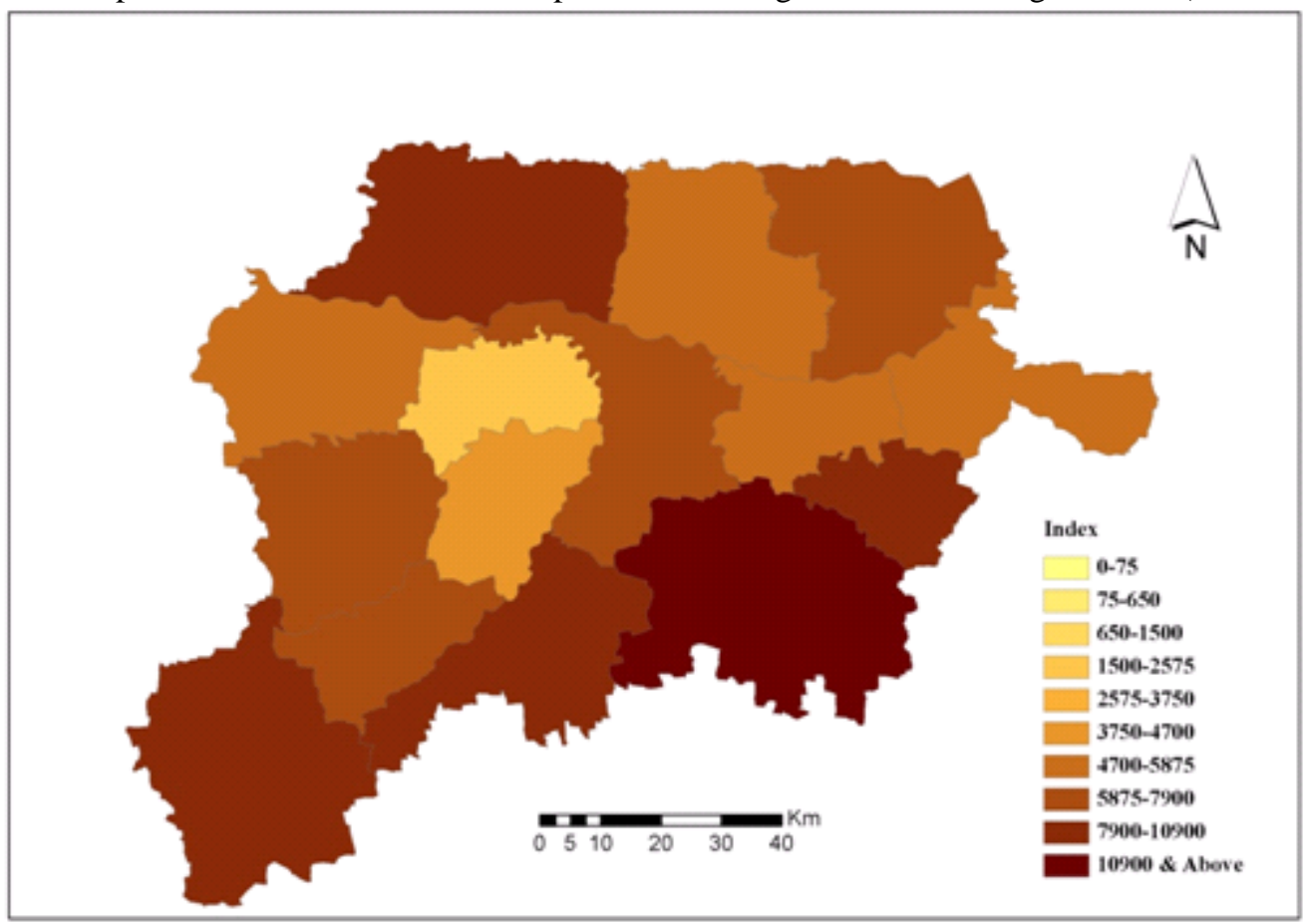

Figure 7:- Spatial distribution Corn crop residues in Jalgaon district during 2009-13 (in Mt. Tons)

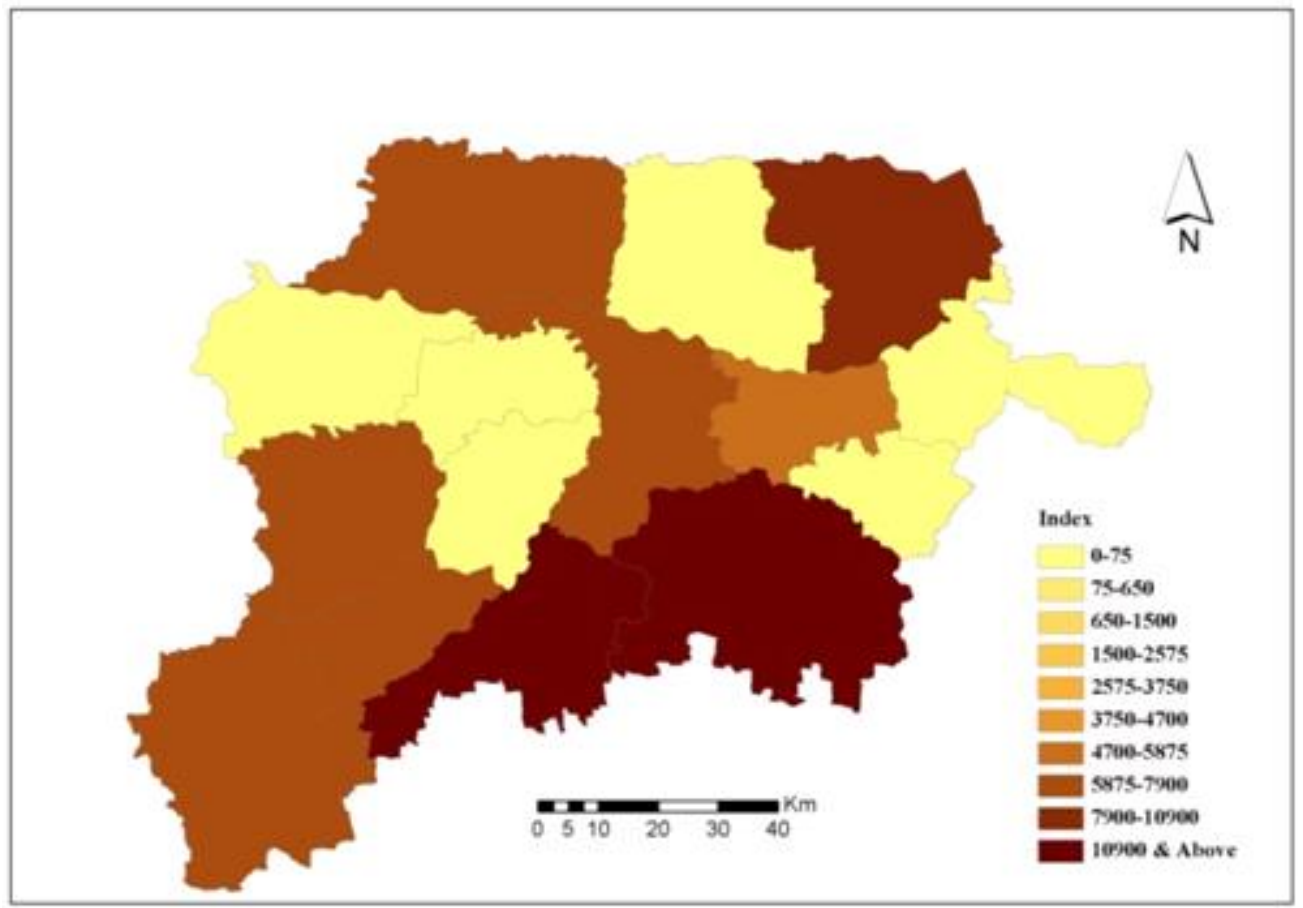




\section{References:-}

1. Demirbaş, A. (2001): Relationships between lignin contents and heating values of biomass. Energy conversion and management. 42(2): 183-188.

2. District Statistical Abstract, (2009): Dist- Jalgaon, Department of Economics and Statistics, State Govt. of Maharashtra, India

3. District Statistical Abstract, (2010): Dist- Jalgaon, Department of Economics and Statistics, State Govt. of Maharashtra, India

4. District Statistical Abstract, (2011): Dist- Jalgaon, Department of Economics and Statistics, State Govt. of Maharashtra, India

5. District Statistical Abstract, (2012): Dist- Jalgaon, Department of Economics and Statistics, State Govt. of Maharashtra, India

6. Guerrero, A.B., Aguado, P.L., Sánchez, J. and Curt, M.D. (2016): GIS-Based Assessment of Banana Residual Biomass Potential for Ethanol Production and Power Generation: A Case Study. Waste and Biomass Valorization: 1-11.

7. Gupta, A. and Verma, J. P. (2015): Sustainable bio-ethanol production from agro-residues: a review. Renewable and Sustainable Energy Reviews, 41: 550-567.

8. Haase, M., Rösch, C. and Ketzer, D. (2016): GIS-based assessment of sustainable crop residue potentials in European regions. Biomass and Bioenergy, 86: 156-171.

9. Jiang, D., Zhuang, D., Fu, J., Huang, Y. and Wen, K. (2012): Bioenergy potential from crop residues in China: Availability and distribution. Renewable and Sustainable Energy Reviews, 16(3):1377-1382.

10. Kumar, A., Kumar, N., Baredar, P. and Shukla, A. (2015): A review on biomass energy resources, potential, conversion and policy in India. Renewable and Sustainable Energy Reviews, 45: 530-539.

11. MNRE- Annual Report 2014-15. (2015): Ministry of New and Renewable Energy, Govt. of India, New Delhi

12. Naik, S., Goud, V.V., Rout, P.K., Jacobson, K. and Dalai, A.K. (2010): Characterization of Canadian biomass for alternative renewable biofuel. Renewable energy, 35(8): 1624-1631.

13. Peidong, Z., Yanli, Y., Guangquan, L. and XinRong, L. (2007): Energy potentiality of crop straw resources in China. Renewable Energy Resources, 25(6): 80-83.

14. Prasad, S., Singh, A. and Joshi, H.C. (2007): Ethanol as an alternative fuel from agricultural, industrial and urban residues. Resources, Conservation and Recycling, 50(1): 1-39.

15. Raj, T., Kapoor, M., Gaur, R., Christopher, J., Lamba, B., Tuli, D.K. and Kumar, R., (2015): Physical and chemical characterization of various Indian agriculture residues for biofuels production. Energy \& Fuels, 29(5):.3111-3118.

16. Sadasivam S. and Manickam A., (2008): Biochemical Methods, New Age International (P) Ltd. Publishers, New Delhi, pp 7-9

17. Sarkar, N., Ghosh, S.K., Bannerjee, S. and Aikat, K., (2012): Bioethanol production from agricultural wastes: An overview. Renewable Energy, 37(1): 19-27.

18. Saxena, R.C., Adhikari, D.K. and Goyal, H.B. (2009): Biomass-based energy fuel through biochemical routes: a review. Renewable and Sustainable Energy Reviews, 13(1): 167-178.

19. Valdez-Vazquez, I., Acevedo-Benítez, J. A. and Hernández-Santiago, C., (2010): Distribution and potential of bioenergy resources from agricultural activities in Mexico. Renewable and Sustainable Energy Reviews, 14(7): 2147-2153. 